\begin{tabular}{cc|c}
\hline Tar. Bil. Der. & Tarım Bilimleri Dergisi & Journal of Agricultural Sciences \\
& $\begin{array}{c}\text { Dergi web sayfası: } \\
\text { www.agri.ankara.edu.tr/dergi }\end{array}$ & Journal homepage: \\
& www.agri.ankara.edu.tr/journal
\end{tabular}

\title{
Production of Multiple Hydrolytic Enzymes by Black Aspergilli Isolated from Date and Grape
}

\author{
Zehra GULSUNOGLU ${ }^{\text {a }}$, Meral KILIÇ AKYILMAZ ${ }^{\text {a }}$, Funda KARBANCIOĞLU GÜLER ${ }^{\text {a }}$, Katleen RAES \\ ${ }^{a}$ Istanbul Technical University, Faculty of Chemical and Metallurgical Engineering, Food Engineering Department, Istanbul, 34469, TURKEY \\ ${ }^{\boldsymbol{b}}$ Ghent University, Faculty of Bioscience Engineering, Department of Industrial Biological Sciences, Kortrijk, 8500, BELGIUM
}

\section{ARTICLE INFO}

Research Article

Corresponding Author: Meral KILIÇ AKYILMAZ, E-mail: meral.kilic@itu.edu.tr, Tel: +90 (212) 2856016

Received: 26 July 2018, Received in Revised Form: 24 September 2018, Accepted: 02 October 2018

\begin{abstract}
Black aspergilli newly isolated from local grape and date were investigated for production of hydrolytic enzymes including cellulase, tannase and pectinase. Isolates were morphologically and molecularly identified as Aspergillus niger, Aspergillus tubingensis, Aspergillus japonicus and Aspergillus aculeatus. Isolates were screened for enzyme production ability on solid and in liquid media. Enzymatic activity was determined in the culture filtrate of liquid medium. A total of six isolates were found to produce multiple hydrolytic enzymes. The highest activity of cellulase was produced by $A$. japonicus ZGM4 and A. aculeatus ZGM6 as 40 and $35 \mathrm{U} \mathrm{g}^{-1}$ dry biomass, respectively. All the isolates exhibited high level of tannase activity in the range of $150-343 \mathrm{U} \mathrm{g} \mathrm{g}^{-1}$ dry biomass after $24 \mathrm{~h}$ of incubation. A. tubingensis ZGM5 and A. aculeatus ZGM6 were found to produce the highest pectinase activity at a level of 130 and $117 \mathrm{Ug}^{-1}$ dry biomass, respectively. In the light of these results, isolates can be used for multiple hydrolytic enzyme production in industry.
\end{abstract}

Keywords: Aspergillus; Cellulase; Pectinase; Tannase

(C) Ankara Üniversitesi Ziraat Fakültesi

\section{Introduction}

Enzymes are widely used in the production of chemicals, food and beverages, pulp and paper, leather, detergents, textiles, biofuels, animal feed, personal care, and pharmaceuticals. Microbial enzymes are preferred as they are relatively more stable, cheaper and have properties more diverse than those originating from plants and animals.

It is important to find a microorganism which has the capacity for producing an enzyme with sufficient activity and yield. In most cases, the scale up of purification methods leads to high loss of yield and operation cost because of multistep procedures (Ma et al 2015). In this respect, enzyme cocktails could be an attractive option for industrial processes utilizing synergistic effect of different enzymes. Aspergillus, Rhizopus and Trichoderma species have been used for production of enzyme cocktails. These cocktails have been utilized for hydrolysing tissues and cell walls of biological materials and releasing juice and functional ingredients for use in food and other industries. They are currently being investigated for valorization of food waste for production of bioactive compounds (Martinez-Avila 
et al 2014; Xu et al 2014; Dulf et al 2016; Karray et al 2016; Buenrostro-Figueroa et al 2017).

One of the most important industrial hydrolytic enzymes is cellulase which breaks the glucosidic bonds of cellulose, releasing oligosaccharides, cellobiose and glucose. This enzyme has been used for improvement of starch and protein extraction, clarification of fruit juice and releasing of antioxidants from fruits and vegetables (Kuhad et al 2011). Pectinases are composed of depolymerizing enzymes such as polygalacturonase (EC 3.2.1), pectin lyase (EC 4.2.2) and decomposting enzymes such as pectin esterase (EC 3.1.1). They have been used for extraction and clarification of fruit juices and wines, maceration of tea leaves and increase the juice and oil extraction yields as well as various biotechnological processes (Ortiz et al 2017). Another important enyzme for the food industry is tannase or tannin acyl hydrolase (EC 3.1.1.20) that catalyses the breakdown of hydrolyzable tannins or gallic acid esters to release glucose and gallic acid. Tannase is used in production of gallic acid and manufacturing of instant tea to prevent haze and sediment formation by the industry (Ma et al 2015).

Several Aspergillus spp. have been discovered which have capacity to produce enzymes. However, the need for isolation of new species which have the ability to produce multiple enzymes from different habitats continues. Local sources can be a good alternative to isolate microorganisms which can produce novel enzymes. Utilization of local sources enables economical and sustainable production and use of industrial enzymes in a country. The aim of this study was to investigate new strains of black aspergilli from local food sources for production of multiple hydrolytic enzymes including cellulase, pectinase and tannase.

\section{Material and Methods}

\subsection{Materials}

Dichloran Glycerol agar (DG18), Dichloran Rose Bengal Chloramphenicol (DRBC) agar, Czapek Yeast Agar with 20\% Sucrose (CY20S), Czapek
Dox Agar (CZ), Czapek Yeast Agar (CYA), and Malt Extract Agar (MEA) were supplied from Merck Chemicals (Darmstadt, Germany). Carboxymethylcellulose sodium salt (CMC), tannic acid, pectin, 3,5-dinitrosalicylic acid (DNS), rhodanine (2-thioxo-4-thiazolidinone), polygalacturonic acid, D-galacturonic acid and gallic acid were purchased from Sigma Chemicals (Taufkirchen, Germany). Yeast extract, agar agar, mycological peptone were purchased from Oxoid (Hampshire, UK). Congo red (Aldrich Chemicals, Taufkirchen, Germany) and Tween 80 (Acros Organic, Geel, Belgium) were also used.

\subsection{Microorganisms}

Aspergillus oryzae MUCL 14492 was supplied from Mycothèque de l'Université Catholique de Louvain (Louvain-la-Neuve, Belgium) and used as reference culture for qualitative screening of enzyme production.

\subsection{Isolation and identification of fungal isolates}

Rotten parts of grape (Vitis vinifera L.) and date (Phoenix dactylifera L.) collected from local markets were transferred onto plates containing MEA, DG18 and DRBC agar after aseptic homogenization in peptone water or directly. Cultures were purified by sub-culturing the spores from black colonies on fresh MEA medium.

Isolated molds were firstly identified according to their macroscopic and microscopic features then molecular identification analysis was performed. Isolated black colonies were grown on CY20S, CZ and MEA media at $25^{\circ} \mathrm{C}$ and CYA medium at 25 and $37^{\circ} \mathrm{C}$. Each colony on all media was examined by determination of colony characteristics by naked eye and micromorphological features (MEA medium) under light microscope for species identification (Raper \& Fennell 1965; Klich 2002).

DNA of molds grown on MEA medium was extracted with Biospeedy Fungal DNA kit (Bioeksen, Istanbul, Turkey). Molecular identification was performed by amplifying internal transcribed spacer region (ITS) using ITS1-5.8S rRNA and ITS2 (5'TCCTCCGCTTATTGATATGC3') as forward 
and (5'GGAAGTAAAAGTCGTAACAAGG3') as reverse primers for real-time quantitative polymerase chain reaction (QPCR) (Schoch et al 2012). QPCR products were purified using PCR Purification Kit (Bio-rad Laboratories, Hercules, CA, USA). DNA sequences were analyzed with Sanger Dideoxy Sequence Termination method using ABI Prism 377 DNA Sequencing Analyser (Applied Biosystems, Foster City, CA, USA). Sequences for $18 \mathrm{~S}$ and ITS regions were compared with the sequences available in National Center for Biotechnology Information (NCBI) database using online BLAST tool (GenBank 2016).

\subsection{Screening of enzymes from solid and liquid media}

Mold suspensions were prepared from 3-day old cultures on MEA slant by adding $5 \mathrm{~mL}$ sterile distilled water with $0.05 \%$ Tween 80 . Disloged mold spores were transferred to a tube aseptically and the tube was centrifuged at $2000 \mathrm{xg}$ at $10{ }^{\circ} \mathrm{C}$ for $20 \mathrm{~min}$. Mold spores were washed two times using peptone water. Molds were enumerated after growth on Sabouraud agar at $30^{\circ} \mathrm{C}$ for $72 \mathrm{~h}$.

Mold suspension (app. $10^{7}$ spores $\mathrm{mL}^{-1}$ ) was inoculated to the middle of the plates containing enzyme specific solid media. Media with CMC (Jayani et al 2005), tannic acid (Bradoo et al 1996) and pectin (Zheng et al 2011) were used for determination of cellulase, tannase and pectinase activity, respectively. Plates were incubated at 30 ${ }^{\circ} \mathrm{C}$ for 72,48 and $72 \mathrm{~h}$ for cellulase, tannase and pectinase, respectively. Enzyme producing isolates were detected by observation of the clear zone around the margins of the colony. Congo red (1\%, $\mathrm{w} / \mathrm{v}$ ) was used to dye the medium for cellulase and pectinase. The media prepared with tannic acid had a purple color which became colorless after hydrolysis by tannase.

Mold suspension with $10^{7}$ spores $\mathrm{mL}^{-1}$ was added to a liquid medium $(25 \mathrm{~mL})$ with the same composition as the solid medium without agar and incubation took place at $30{ }^{\circ} \mathrm{C}$ in a shaking incubator at $200 \mathrm{rpm}$. Culture filtrate from Whatman filter paper (pore size 5-13 $\mu \mathrm{m}$ ) was used as the crude extracellular enzyme source. Mycelial biomass was dried to a constant weight at $105{ }^{\circ} \mathrm{C}$ for $24 \mathrm{~h}$ to determine the biomass yield. $\mathrm{pH}$ of the filtrate was measured using $\mathrm{pH}$ meter to follow $\mathrm{pH}$ changes. Cellulase and pectinase enzymes were assayed according to the DNS method (Debing et al 2006; Sridevi \& Charya 2011). One unit of enzyme is defined as the amount of enzyme that liberates $1 \mu \mathrm{mol}$ of glucose and galacturonic acid by the enzyme per minute under the assay conditions for cellulase and pectinase, respectively. Tannase activity was determined by method described by Lagemaat \& Pyle (2001). Tannase activity was expressed as $\mu \mathrm{mol}$ of gallic acid released per minute under the assay conditions.

\subsection{Statistical analysis}

Experiments and analyses were carried out in triplicate. Data were subjected to one-way analysis of variance (ANOVA). Means were compared by Tukey's test at a significance level of 0.05 (Minitab 16, Minitab Inc, Coventry, UK).

\section{Results and Discussion}

\subsection{Isolation and identification of black aspergilli from local sources}

Eight of the black colonies that grew on date and grape with different morphology were isolated for morphological and molecular identification. All isolated molds produced pigmentation with modest color yields such as brownish-black to black in front and cream to yellow in reverse of agar media. The isolates were found to exhibit features of Aspergillus species under the section of Nigri in micromorphological analysis. The strains belonging to Aspergillus section Nigri characteristically present dark-brown to black conidia, uniseriate or biseriate conidiophores, spherical vesicles and hyaline or lightly pigmented hyphae.

The molecular analysis showed that isolates belonged to genus Aspergillus (Table 1). The isolates ZDM1 and ZGM5 belong to the species A. tubingensis, ZDM2 and ZDM3 were classified as $A$. niger, ZGM4 and ZGM6 were $A$. japonicus 
and A. aculeatus, respectively. Morphological and molecular identification findings were in agreement. Two of the colonies were found to be similar according to molecular and morphological identifications and therefore six molds were selected for further studies.

\subsection{Screening of isolates for enzyme production on solid medium}

Qualitative screening was performed by the hydrolysis of substrate on solid agar medium. All isolates had the ability to produce cellulase, tannase and pectinase enzymes (Table 2). The activity was detected around the colonies by the appearance of a clear zone revealed by hydrolysis of substrate. In the case of molds which did not produce any enzyme, growth was restricted and no clear zone observed.

Aspergillus oryzae MUCL 14492 was employed in screening on solid medium as a reference culture. This culture has been extensively used before particularly for synthesis of cellulase, tannase and pectinolytic enzymes (Heerd et al 2012; Pirota et al 2016; Koseki et al 2018). There were no significant differences between levels of cellulase and pectinase displayed on solid medium by the isolates and the reference culture. A. japonicus ZGM4 and A. aculeatus ZGM6 showed the highest tannase activity compared to those of the other isolates and the reference culture exhibited the lowest tannase activity. Taskin et al (2008) and Murugan et al (2007) also reported that Aspergillus spp. can produce these enzymes on solid media.

Some researchers found a high correlation between the levels of enzyme production determined by screening on solid and in liquid media (Ten et al 2004; Murugan et al 2007). However, in another study, a mold identified as an enzyme producer by plate screening method did not produce any enzymes in liquid medium (Tseng et al 2000). Therefore, enzyme production by a mold needs to be confirmed in liquid medium.

Table 1- Identification of isolates from grape and date on sequences

\begin{tabular}{lllll}
\hline Isolate code & Species & Gen bank code & Identities (\%) & Source \\
\hline ZDM1 & Aspergillus tubingensis & KP131626 & $589 / 594(99)$ & Date \\
ZDM2 & Aspergillus niger & KT852982 & $566 / 568(99)$ & Date \\
ZDM3 & Aspergillus niger & KT898789 & $557 / 558(99)$ & Date \\
ZGM4 & Aspergillus japonicus & KC128815 & $560 / 568(99)$ & Grape \\
ZGM5 & Aspergillus tubingensis & GU595290 & $574 / 576(99)$ & Grape \\
ZGM6 & Aspergillus aculeatus & JF439460 & $546 / 550(99)$ & Grape \\
\hline
\end{tabular}

Table 2- Clear zone diameter of Aspergillus spp. measured by plate screening method

\begin{tabular}{llll}
\hline \multirow{2}{*}{ Isolates } & Cellulase & Tannase & Pectinase \\
\cline { 2 - 4 } & \multicolumn{3}{l}{ Clear zone $(\mathrm{mm})^{*}$} \\
\hline Aspergillus oryzae MUCL 14492 & $49.8 \pm 4.9^{\mathrm{a}}$ & $15.5 \pm 0.4^{\mathrm{c}}$ & $38.3 \pm 1.4^{\mathrm{a}}$ \\
Aspergillus tubingensis ZDM1 & $51.8 \pm 7.1^{\mathrm{a}}$ & $22.7 \pm 2.3^{\mathrm{b}}$ & $29.6 \pm 8.1^{\mathrm{a}}$ \\
Aspergillus niger ZDM2 & $53.9 \pm 7.7^{\mathrm{a}}$ & $22.9 \pm 2.0^{\mathrm{b}}$ & $36.4 \pm 10.4^{\mathrm{a}}$ \\
Aspergillus niger ZDM3 & $57.1 \pm 6.2^{\mathrm{a}}$ & $22.0 \pm 2.3^{\mathrm{b}}$ & $30.5 \pm 6.7^{\mathrm{a}}$ \\
Aspergillus japonicus ZGM4 & $49.3 \pm 5.9^{\mathrm{a}}$ & $30.3 \pm 1.0^{\mathrm{a}}$ & $28.4 \pm 5.5^{\mathrm{a}}$ \\
Aspergillus tubingensis ZGM5 & $54.4 \pm 8.0^{\mathrm{a}}$ & $22.2 \pm 2.5^{\mathrm{b}}$ & $37.8 \pm 7.3^{\mathrm{a}}$ \\
Aspergillus aculeatus ZGM6 & $51.0 \pm 7.4^{\mathrm{a}}$ & $28.9 \pm 1.9^{\mathrm{a}}$ & $30.7 \pm 9.2^{\mathrm{a}}$ \\
\hline
\end{tabular}

*, Mean \pm Standard deviation ( $\mathrm{n}=3$ ); Means marked with different letters in the same column are significantly different $(\mathrm{P}<0.05)$ 


\subsection{Screening of isolates for enzyme production in liquid medium}

Biomass of all isolates did not change significantly after the first day of incubation in medium used for cellulase $\left(5.36 \pm 1.22 \mathrm{mg} \mathrm{mL}^{-1}\right)$ and pectinase (5.71 $\left.\pm 0.15 \mathrm{mg} \mathrm{mL}^{-1}\right)$ production. Biomass increased at the beginning of incubation $\left(3.76 \pm 0.51 \mathrm{mg} \mathrm{mL}^{-1}\right)$ and then remained constant until the end of incubation in the case of tannase.

\subsubsection{Cellulase}

The $\mathrm{pH}$ value of the medium did not change during incubation. Cellulase activity of all isolates increased during the incubation period and peak activity was achieved after $96 \mathrm{~h}$ (Figure 1). The highest cellulase activity was produced by $A$. japonicus ZGM4 with a peak activity of $40 \pm 4.5$ $\mathrm{U} \mathrm{g}^{-1}$ dry biomass $\left(3.8 \pm 0.5 \mathrm{U} \mathrm{mL}^{-1}\right)$. Peak enzyme activity of isolates of Aspergillus spp. expressed per volume of medium was ranged between 2-3.8 U $\mathrm{mL}^{-1}$, except $A$. tubingensis ZGM5 which produced an activity of $0.56 \mathrm{U} \mathrm{mL}^{-1}$. Gautam et al (2011) reported the peak cellulase activity for $A$. niger after $96 \mathrm{~h}$ of incubation as $1.8 \mathrm{U} \mathrm{mL}^{-1}$. Imran et al (2017) also reported that cellulase activity of $A$. tubingensis IMMIS2 increased continuously up to $96 \mathrm{~h}$ and then decreased. Enzyme activity fluctuated in some isolates which can be explained by catabolite repression from excess product during degradation of cellulose (Ang et al 2013).

\subsubsection{Tannase}

A. niger ZDM2 and A. japonicus ZGM4 exhibited the highest tannase activity at $326 \pm 57 \mathrm{U} \mathrm{g}^{-1}$ dry biomass and $343 \pm 107 \mathrm{U} \mathrm{g}^{-1}$ dry biomass, respectively, after $24 \mathrm{~h}$ of incubation (Figure 2). All isolates were found to produce higher activity of tannase compared to those reported in the literature for Aspergillus spp. by Banerjee et al (2007) and Murugan et al (2007). Lal et al (2012) reported higher tannase activity than those in this study for A. niger isolated from bark of Acacia nilotica which contained high level of tannin.

There are differences in reported incubation times for maximum tannase activity in the

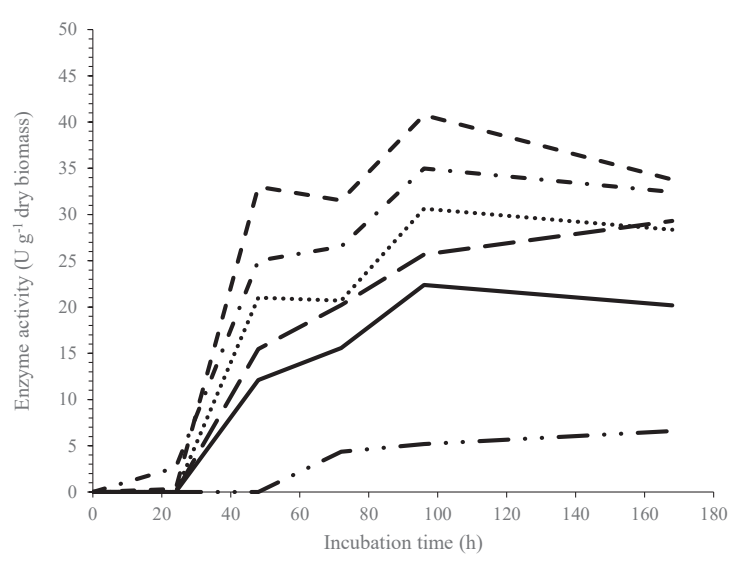

Figure 1- Change in cellulase activity of Aspergillus spp. during seven days of incubation $(\mathrm{n}=3) . A$. tubingensis ZGM5 (॰०); A. tubingensis ZGM1 (); $A$. niger ZDM3 (॰); A. niger ZDM2 (・・); A. aculeatus ZGM6 (•); A. japonicus ZGM4 (-)

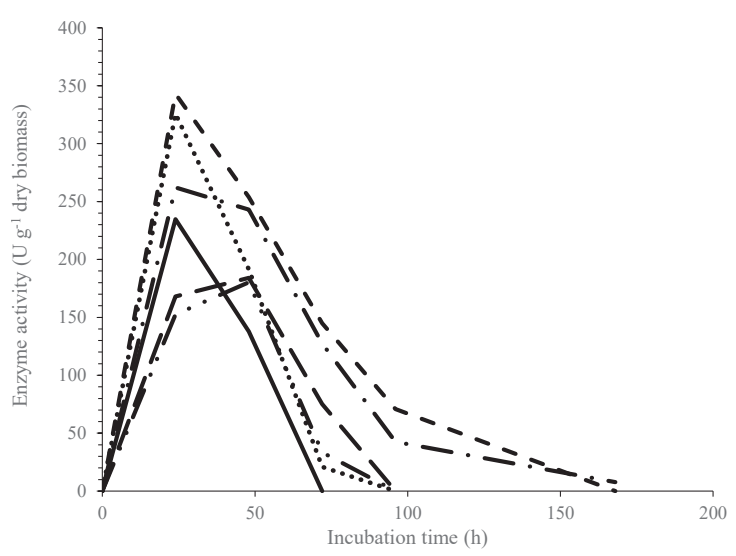

Figure 2- Change of tannase activity of Aspergillus spp. during seven days of incubation $(\mathrm{n}=3) . A$.

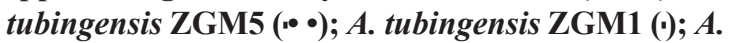
niger ZDM3 (॰); A. niger ZDM2 (•・•); A. aculeatus ZGM6 (•); A. japonicus ZGM4 (-)

literature. Yadav et al (2008) found that maximum tannase production by $A$. fumigatus was obtained after $96 \mathrm{~h}$ of incubation, whereas Banerjee et al (2007) found a maximum tannase production by $A$. aculeatus after $72 \mathrm{~h}$ of incubation. In this study, the highest tannase activity was obtained 
after $24 \mathrm{~h}$ incubation and then there was a decline for all Aspergillus spp. The reason for the decline in enzyme production can be explained by the accumulation of end-products like gallic acid and secretion of toxic substances like catechuic acid, benzoic acid and pyrogallol which can cause cell disruption (Kar \& Banerjee 2000). Previous studies also reported that pyrogallols, gallic acid and gallaldehyde can inhibit the tannase activity of A. niger (Srivastava \& Kar 2009).

The $\mathrm{pH}$ changes could also affect tannase enyzme production negatively, because tannase enzyme is an acidic protein and its optimum $\mathrm{pH}$ is around 5.5 (Banerjee et al 2007). Initial $\mathrm{pH}$ of the medium was around 4 and it declined to 3 after 1 day of incubation. It started to increase after 2 days of incubation and it reached to 6-7 after 7 days of incubation. The increase in the $\mathrm{pH}$ can be due to the consumption of tannic acids or the production of alkaline compounds during the incubation time (Zeni et al 2011). Lal et al (2012) also reported similar trend for tannase activity of A. niger with $\mathrm{pH}$ changes where maximum activity was observed at $\mathrm{pH} 5.0$, and tannase activity start to decrease when the $\mathrm{pH}$ of medium reached the alkaline range.

\subsubsection{Pectinase}

All isolates produced pectinase but the incubation time for peak activity was changed according to the isolate (Figure 3). Highest activity of pectinase $\left(130 \pm 66.2 \mathrm{U} \mathrm{g}^{-1}\right.$ dry biomass; $\left.25 \pm 1.5 \mathrm{U} \mathrm{mL}^{-1}\right)$ was obtained from A. tubingensis ZGM5. Taskin et al (2008) reported pectinase production by Aspergillus spp. isolated from vineyards with activity in the range of 44-122 $\mathrm{U} \mathrm{mL}^{-1}$. The difference between these results could be due to the composition of the media and the method used for determination of activity.

For pectinase enzyme, $\mathrm{pH}$ of medium showed fluctuations during incubation time depending on the isolate. $\mathrm{pH}$ of liquid medium used for all isolates decreased from 4.5 to 3-3.5 after 3 days of incubation. An increase in $\mathrm{pH}$ to 5.5 was observed for A. japonicus ZGM4 and A. aculeatus ZGM6

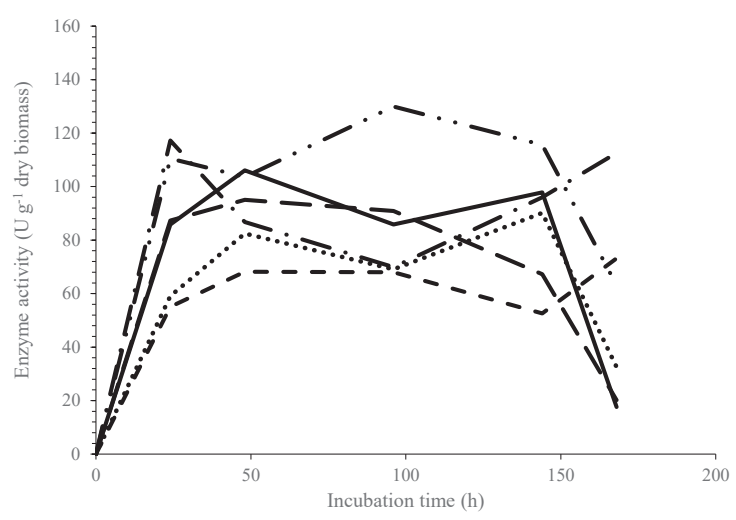

Figure 3- Change of pectinase activity of Aspergillus spp. during seven days of incubation $(\mathrm{n}=3)$. $A$. tubingensis ZGM5 ( $\bullet \bullet)$; $A$. tubingensis ZGM1 ('); $A$. niger ZDM3 (॰); A. niger ZDM2 (••); A. aculeatus ZGM6 (•); $A$. japonicus ZGM4 (-)

while the $\mathrm{pH}$ remained constant for other isolates after 4 days. Mahesh et al (2016) reported that $\mathrm{pH} 4$ was optimum for pectinase production by Aspergillus ibericus and increase in fermentation medium $\mathrm{pH}$ from 3 to 4 increased the production of pectinase after that activity started to decrease with increasing $\mathrm{pH}$. The increase in $\mathrm{pH}$ can be caused by consumption of organic acids by molds as nutrients because of a lack of carbon source (Botella et al 2005). The decrease in $\mathrm{pH}$ can be related to the release of galacturonic acid to the medium due to the action of pectinase enzymes of the molds during the first day of incubation (Zeni et al 2011).

The enzyme production is generally associated with the growth phase of microorganisms. For some isolates, there was a decline in activity of tannase and pectinase after a few days of incubation. This decline might be explained with the hydrolysis of the produced enzymes by isolates due to lack of nutrients in fermentation media (Botella et al 2005). In addition, changes in the fermentation conditions such as $\mathrm{pH}$ and production of inhibitory substances compared to the starting conditions could affect the activity of enzymes (Gautam et al 2011; Zeni et al 2011). 


\section{Conclusions}

This study showed that newly isolated black Aspergillus spp. have good potential for use as a source of hydrolytic enzymes. All isolates produced tannase with high activity, however $A$. japonicus ZGM4 and A. aculeatus ZGM6 were found to be the best isolates for producing tannase. Additionally, A. tubingensis ZGM5 can produce tannase and pectinase, while it was not competent to produce cellulase with high activity. Among the isolated molds, $A$. aculeatus ZGM6 had the ability to produce all studied hydrolytic enzymes at a high activity. Isolates from this study can be utilized as a source for multiple enzyme production after further studies on optimization of fermentation conditions and scale-up.

\section{References}

Ang S K, Shaza E M, Adibah Y, Suraini A A \& Madihah M S (2013). Production of cellulases and xylanase by Aspergillus fumigatus SK1 using untreated oil palm trunk through solid state fermentation. Process Biochemistry 48(9): 1293-1302

Banerjee D, Mondal K \& Pati B (2007). Tannase production by Aspergillus aculeatus DBF9 through solid state fermentation. Acta Microbiologica et Immunologica Hungarica 54(2): 159-166

Botella C, De Ory I, Webb C, Cantero D \& Blandino A (2005). Hydrolytic enzyme production by Aspergillus awamori on grape pomace. Biochemical Engineering Journal 26(2): 100-106

Bradoo S, Gupta R \& Saxena R K (1996). Screening of extracellular tannase-producing fungi: Development of a rapid and simple plate assay. Journal of General and Applied Microbiology 42: 325-329

Buenrostro-Figueroa J J, Velázquez M, Flores-Ortega $\mathrm{O}$, Ascacio-Valdés J A, Huerta-Ochoa S, Aguilar C N \& Prado-Barragán L A (2017). Solid state fermentation of fig (Ficus carica L.) by-products using fungi to obtain phenolic compounds with antioxidant activity and qualitative evaluation of phenolics obtained. Process Biochemistry 62: 16-23

Debing J, Peijun L, Stagnitti F, Xianzhe X \& Ling L (2006). Pectinase production by solid fermentation from Aspergillus niger by a new prescription experiment. Ecotoxicology and Environmental Safety 64(2): 244-250

Dulf F V, Vodnar D C \& Socaciu C (2016). Effects of solid-state fermentation with two filamentous fungi on the total phenolic contents, flavonoids, antioxidant activities and lipid fractions of plum fruit (Prunus domestica L.) by-products. Food Chemistry 209: 2736

Gautam S P, Bundela P S, Pandey A K, Khan J, Awasthi M K \& Sarsaiya S (2011). Optimization for the production of cellulase enzyme from municipal solid waste residue by two novel cellulolytic fungi. Biotechnology Research International 2011: 1-8

GenBank (2016). National Center for Biotechnology Information (NCBI), US National Library of Medicine. Retrieved in June, 25, 2016 from http:// www.ncbi.nlm.nih.gov/

Heerd D, Yegin S, Tari C \& Fernandez-Lahore M (2012). Pectinase enzyme-complex production by Aspergillus spp. in solid-state fermentation: A comparative study. Food and Bioproducts Processing 90(2): 102-110

Imran M, Anwar Z, Irshad M, Javid A, Hussain A \& Ali S (2017). Optimization of cellulase production from a novel strain of Aspergillus tubingensis IMMIS2 through response surface methodology. Biocatalysis and Agricultural Biotechnology 12: 191-198

Jayani R S, Saxena S \& Gupta R (2005). Microbial pectinolytic enzymes: A review. Process Biochemistry 40(9): 2931-2944

Kar B \& Banerjee R (2000). Biosynthesis of tannin acyl hydrolase from tannin-rich forest residue under different fermentation conditions. Journal of Industrial Microbiology and Biotechnology 25(1): 29-38

Karray R, Hamza M \& Sayadi S (2016). Production and characterization of enzymatic cocktail produced by Aspergillus niger using green macroalgae as nitrogen source and its application in the pre-treatment for biogas production from Ulva rigida. Bioresource Technology 216: 622-628

Klich M A (2002). Identification of Common Aspergillus Species. Centraalbureau voor Schimmelcultures, Utrecht

Koseki T, Ichikawa K, Sasaki K \& Shiono Y (2018). Characterization of a novel Aspergillus oryzae tannase expressed in Pichia pastoris. Journal of Bioscience and Bioengineering In press, DOI: 10.1016/j. jbiosc.2018.05.010 
Kuhad R C, Gupta R \& Singh A (2011). Microbial cellulases and their industrial applications. Enzyme Research 2011: 1-10

Lagemaat J V D \& Pyle D L (2001). Solid-state fermentation and bioremediation: Development of a continuous process for the production of fungal tannase. Chemical Engineering Journal 84: 115-123

Lal D, Shrivastava D, Verma H N \& Gardner J J (2012). Production of nannin acyl hydrolase (EC 3.1. 1.20) from Aspergillus niger isolated from bark of Acacia nilotica. Journal of Microbiology and Biotechnology Research 2(4): 566-572

Ma W L, Zhao F F, Ye Q, Hu Z X, Yan D, Hou J \& Yang Y (2015). Production and partial purification of tannase from Aspergillus ficuum Gim 3.6. Preperation of Biochemical and Biotechnology 45: 754-768

Mahesh M, Arivizhivendhan K V, Maharaja P, Boopathy R, Hamsavathani V \& Sekaran G (2016). Production, purification and immobilization of pectinase from Aspergillus ibericus onto functionalized nanoporous activated carbon (FNAC) and its application on treatment of pectin containing wastewater. Journal of Molecular Catalysis B: Enzymatic 133: 43-54

Martinez-Avila G C G, Aguilera A F, Saucedo S, Rojas R, Rodriguez R \& Aguilar C N (2014). Fruit wastes fermentation for phenolic antioxidants production and their application in manufacture of edible coatings and films. Critical Reviews in Food Science and Nutrition 54(3): 303-311

Murugan K, Saravanababu S \& Arunachalam M (2007). Screening of tannin acyl hydrolase (E.C.3.1.1.20) producing tannery effluent fungal isolates using simple agar plate and smf process. Bioresource Technology 98(4): 946-949

Ortiz G E, Ponce-Mora M C, Noseda D G, Cazabat G, Saravalli C, Lopez M C, Gil G P, Blasco M \& Alberto E O (2017). Pectinase production by Aspergillus giganteus in solid-state fermentation: Optimization, scale-up, biochemical characterization and its application in olive-oil extraction. Journal of Industrial Microbiology \& Biotechnology 44(2): 197211

Pirota R D P B, Tonelotto M, Delabona P S, Fonseca R F, Paixao D A A, Baleeiro F C F, Bertucci Neto V \& Farinas C S (2016). Bioprocess developments for cellulase production by Aspergillus oryzae cultivated under solid-state fermentation. Brazilian Journal of Chemical Engineering 33(1): 21-31
Raper K B \& Fennell D I (1965). The Genus Aspergillus. Williams \& Wilkins, Baltimore

Schoch C L, Seifert K A, Huhndorf S, Robert V, Spouge J L, Levesque C A, Chen W \& Consortium F B (2012). Nuclear ribosomal internal transcribed spacer (ITS) region as a universal DNA barcode marker for fungi. Proceedings of the National Academy of Sciences 109(16): 6241-6246

Sridevi B \& Charya M A S (2011). Isolation, identification and screening of potential cellulase-free xylanase producing fungi. African Journal of Biotechnology 10(22): 4624-4630

Srivastava A \& Kar R (2009). Characterization and application of tannase produced by Aspergillus niger ITCC 6514.07 on pomegranate rind. Brazilian Journal of Microbiology 40(4): 782-789

Taskin E, Eltem R, da Silva E S \& de Souza J V B (2008). Screening of Aspergillus strains isolated from vineyards for pectinase production. Journal of Food Agriculture and Environment 6(3-4): 412-414

Ten L N, Im W T, Kim M K, Kang M S \& Lee S T (2004). Development of a plate technique for screening of polysaccharide-degrading microorganisms by using a mixture of insoluble chromogenic substrates. Journal of Microbiological Methods 56(3): 375-382

Tseng Y H, Fang T J \& Tseng S M (2000). Isolation and characterization of a novel phytase from Penicillium simplicissimum. Folia Microbiologica 45: 121-127

Xu C, Yagiz Y, Borejsza-Wysocki W, Lu J, Gu L, RamirezRodrigues M M \& Marshall M R (2014). Enzyme release of phenolics from muscadine grape (Vitis rotundifolia Michx.) skins and seeds. Food Chemistry 157: 20-29

Yadav A, Aggarwal N K, Kumar K \& Kumar A (2008). Tannase production by Aspergillus fumigatus MA under solid-state fermentation. World Journal of Microbiology and Biotechnology 24(12): 3023-3030

Zeni J, Cence K, Grando C E, Tiggermann L, Colet R, Lerin L A, Cansian R L, Toniazzo G, Oliveira D \& Valduga E (2011). Screening of pectinase-producing microorganisms with polygalacturonase activity. Applied Biochemistry Biotechnology 163(3): 383-392

Zheng L, Du B \& Xue W (2011). Screening and identification of Acinetobacter junii for Apocynum vernetum L. fiber enzymatic retting. Journal of Textile Institute 102(8): 675-680 